\title{
Two cases of vitamin D intoxication
}

\author{
*Md Fekarul Islam ${ }^{1}$, Devdeep Mukherjee ${ }^{1}$, Tarun Kumar ${ }^{1}$, Ritabrata Kundu ${ }^{1}$, Joydeep Das ${ }^{1}$
}

Sri Lanka Journal of Child Health, 2017; 46(3): 275-277

DOI: http://dx.doi.org/10.4038/sljch.v46i3.8332

(Key-words: Vitamin D intoxication, Hypervitaminosis D, Zoledronate)

\section{Introduction}

There is no consensus yet regarding the dose of vitamin $\mathrm{D}$ which may lead to intoxication, but maintenance dose of vitamin $\mathrm{D}$ has been reported to be safe at $1000 \mathrm{IU} /$ day for ages $0-1$ year, 2500 $\mathrm{IU} /$ day for ages 1-3 years, $3000 \mathrm{IU} /$ day for ages 3-8 years, and $4000 \mathrm{IU} /$ day for age 9 years and above ${ }^{1}$.

\section{Case 1}

A 7 year old girl was admitted with vomiting for 5 days and constipation for 7 days. She was also having migratory arthritis of both knees and ankles for 2 months for which she had been prescribed oral cholecalciferol (Vitamin D), 60,000 IU weekly prophylactically, considering her to be possibly having vitamin D deficiency, although she had not been tested for it. The history revealed that she had been taking the vitamin D sachet $(60,000 \mathrm{IU})$ twice a day for the last 4 weeks, instead of one sachet per week. On admission, her vital signs were stable. Her liver and spleen were palpable $3 \mathrm{~cm}$ and $2 \mathrm{~cm}$ below the costal margin respectively. The blood urea was $50 \mathrm{mg} / \mathrm{dl}$ and the serum creatinine $0.5 \mathrm{mg} / \mathrm{dl}$. The serum calcium was $12.2 \mathrm{mg} / \mathrm{dl}$ (normal 8.6-10.2 $\mathrm{mg} / \mathrm{dl})$ and the urinary calcium: creatinine $(\mathrm{Ca}: \mathrm{Cr})$ ratio was 0.88 (normal $<0.25$ ). The vitamin $\mathrm{D}$ level was $312 \mathrm{ng} / \mathrm{ml}$. Urine microscopy showed $25-30 \mathrm{red}$ blood cells per high power field. Ultrasound scan of the abdomen did not show any nephrocalcinosis.

We initiated rehydration therapy with normal saline (1.5 times maintenance fluid) and intravenous (IV) frusemide in a dose of $4 \mathrm{mg} / \mathrm{kg} /$ day. However, 5 days after conservative management, the serum calcium level increased to $13.0 \mathrm{mg} / \mathrm{dl}$. A single dose of zoledronic acid injection $5 \mathrm{mg} / 100 \mathrm{ml}$ was administered because of persistent hypercalcaemia. Three days later, the blood urea was $33 \mathrm{mg} / \mathrm{dl}$, the serum creatinine $0.4 \mathrm{mg} / \mathrm{dl}$, the serum calcium $8.7 \mathrm{mg} / \mathrm{dl}$, the urinary $\mathrm{Ca}: \mathrm{Cr}$ ratio 0.67 and the vitamin D level had come down to $143 \mathrm{ng} / \mathrm{ml}$.

\begin{tabular}{l}
\hline${ }^{1}$ Institute of Child Health, Kolkata, India \\
*Correspondence: fekarulich@gmail.com \\
(Received on 11 February 2016: Accepted after \\
revision on 22 April 2016) \\
The authors declare that there are no conflicts of \\
interest \\
Personal funding was used for this project. \\
Open Access Article published under the Creative
\end{tabular}

Commons Attribution CC-BY CC License.
Subsequently she was found to have decreased serum complement levels (C3 and C4). Her antinuclear antibody was positive and anti-double stranded DNA was positive in 1:160 titre with speckled pattern. Clinical parameters and blood reports were suggestive of systemic lupus erythematosus (SLE) and renal biopsy confirmed class III lupus nephritis. This explained her prolonged arthritis. Treatment was initiated with prednisolone, hydroxychloroquine and azathioprine. On follow up after 4 weeks, the vitamin D level was $112 \mathrm{ng} / \mathrm{ml}$ and the serum calcium $10.2 \mathrm{mg} / \mathrm{dl}$. At one year follow up her vitamin D level was $32 \mathrm{ng} / \mathrm{ml}$. She is presently on treatment for SLE.

\section{Case 2}

An 8 month old male child was admitted with a complaint of not gaining weight since 3 months and constipation and polyuria since 1 month. On admission, he was irritable. He had a body weight of $4.2 \mathrm{~kg}\left(<3^{\text {rd }}\right.$ centile). He was born at 7 months gestation and had a birth weight of $1.7 \mathrm{~kg}$. His vital signs were normal. Mother complained of her baby not gaining weight after introduction of vitamin supplements which were given daily for 2 months prior to admission. The blood urea was $46 \mathrm{mg} / \mathrm{dl}$ and the serum creatinine $0.3 \mathrm{mg} / \mathrm{dl}$. The serum calcium was $14.2 \mathrm{mg} / \mathrm{dl}$ and the urinary $(\mathrm{Ca}: \mathrm{Cr}$ ) ratio was 0.92. The vitamin D level was $402 \mathrm{ng} / \mathrm{ml}$. Ultrasound scan of the abdomen did not show any nephrocalcinosis.

He was treated with IV fluids (rehydration therapy) and frusemide was given at $3 \mathrm{mg} / \mathrm{kg} /$ day in 3 divided doses. Following treatment repeat investigations showed a blood urea of $37 \mathrm{mg} / \mathrm{dl}$, a serum creatinine of $0.3 \mathrm{mg} / \mathrm{dl}$, a serum calcium of $9.8 \mathrm{mg} / \mathrm{dl}$, a urinary (Ca: $\mathrm{Cr}$ ) ratio of 0.6 and a vitamin D level of 147 $\mathrm{ng} / \mathrm{ml}$. Gradually he started accepting feeds well. Further work up for poor weight gain did not reveal any abnormality. At 2 months follow up he had a weight of $6.5 \mathrm{~kg}$, a serum calcium of $9.8 \mathrm{mg} / \mathrm{dl}$ and a vitamin D level of $108 \mathrm{ng} / \mathrm{ml}$.

\section{Discussion}

The Indian subcontinent has a prevalence $50-90 \%$ of children suffering from Vitamin D deficiency. Dietary deficiency and skin colour are some of the factors which contribute to this deficiency ${ }^{1}$. Recent guidelines have categorized vitamin $\mathrm{D}$ levels $[25(\mathrm{OH}) \mathrm{D}]$ as severe deficiency $(<5 \mathrm{ng} / \mathrm{ml})$, deficiency $(<15 \mathrm{ng} / \mathrm{ml})$, sufficiency $(>20 \mathrm{ng} / \mathrm{ml})$ and 
risk for toxicity $(>50 \mathrm{ng} / \mathrm{ml})^{2}$. Hypervitaminosis D (HD) manifests when the levels exceed $150 \mathrm{ng} / \mathrm{ml}^{3-4}$. There has been a trend to administer over the counter vitamin $\mathrm{D}$ to the paediatric population especially to infants and children suffering from bone and joint pain $^{3-5}$. Prescription errors are also common. This has contributed to the increasing risk of children being diagnosed to have $\mathrm{HD}^{4-7}$

Symptoms of vitamin D intoxication (VDI) arise from the deposition of calcium phosphate crystals within the soft tissues of the body thereby giving rise to poor appetite, nausea, vomiting, constipation, growth retardation, polyuria, dehydration and fever secondary to hypercalcaemia ${ }^{3-4,7}$. Our patients had vomiting and constipation on admission. Our second case also had failure to gain weight and polyuria which can also happen in prolonged hypercalcaemia ${ }^{5}$. Both our patients had 25(OH)D levels beyond $150 \mathrm{ng} / \mathrm{ml}$ and hence were diagnosed to have HD. Serum calcium and urine $\mathrm{Ca} / \mathrm{Cr}$ ratio were also beyond the normal range.

The treatment of VDI focuses on control of hypercalcaemia and immediate removal of the exogenous source. We immediately stopped the oral supplementation of Vitamin D. Rehydration decreases serum calcium level by dilution and corrects prerenal azotaemia. It also increases urine output and thereby calcium excretion. Normal saline, with or without a loop diuretic, is often adequate for treating mild or moderate hypercalcaemia ${ }^{3-5}$. Both our patients were given rehydration therapy (1.5 times maintenance fluid) with furosemide. Our second case responded well to fluids and diuretics alone. However, our first case did not show adequate response as her serum calcium went up further.

More significant hypercalcaemia requires glucocorticoids, calcitonin and bisphosphonates. Glucocorticoids decrease intestinal absorption of calcium. Usual dosage of prednisone is 1-2 $\mathrm{mg} / \mathrm{kg} / 24 \mathrm{hr}$. Prednisolone for our first patient served as treatment for hypercalcaemia as well as SLE (diagnosed during her hospital stay). Calcitonin also lowers calcium by inhibiting bone resorption. Bisphosphonates inhibit bone resorption through their effects on osteoclasts and have a very rapid response ${ }^{3}$. Zoledronic acid $(5 \mathrm{mg} / 100 \mathrm{ml})$ is infused over at least 15 minutes, usually as a single dose. A second dose may be repeated depending on the initial response ${ }^{6}$. A review of literature suggests the role of Pamidronate in treatment of hypercalcemia of adults ${ }^{5}$. Zoledronic acid, although not recommended in children, was given because of unavailability of other bisphosphonates ${ }^{8-9}$. Our first case responded well to a single dose of zoledronic acid. Haemodialysis rapidly lowers serum calcium in patients with refractory severe hypercalcaemia.
Vitamin D should also be eliminated from the $\operatorname{diet}^{2,7}$. In both our patients we eliminated vitamin D fortified food (milk, milk products like cheese and egg yolk). Sunscreen lotion was advised to the first child for HD as well as for SLE. All patients with persistent, nonspecific musculoskeletal pain are at high risk for the consequences of unrecognized and untreated severe HD as we saw in our first patient. Even patients on long term steroids with prophylactic calcium supplements have been documented to have $\mathrm{HD}^{10}$. Our second child was receiving vitamin D supplements prophylactically.

We present these cases to create awareness about VDI as vitamin D is usually taken without prescription, and physicians should preferably measure vitamin D level prior to prescribing it.

\section{References}

1. Harinarayanan CV, Joshi SR. Vitamin D status in India: Its implications and remedial measures. Journal of the Association of Physicians of India. 2009; 57: $40-8$

2. Ross AC, Manson JE, Abrams SA, Aloia JF, Brannon PM, Clinton SK, et al. The 2011 report on dietary reference intakes for calcium and vitamin D from the Institute Of Medicine: What clinicians need to know? Journal of Clinical Endocrinology and Metabolism 2011; 96:53-8

http://dx.doi.org/10.1210/jc.2010-2704 PMid: 21118827 PMCid: PMC3046611

3. Greenbaum LA. Rickets and hypervitaminosis D. In: Kliegman R, Stanton B, St. Geme J, Schor N, editors. Nelson Textbook of Paediatrics $20^{\text {th }}$ ed. Elsevier; 2015. Chapter 51, P 340-1.

4. Ahmad IA, Al-Agha AE. Hypervitaminosis D causing nephrogenic diabetes insipidus in a 5-month-old infant. Saudi Medical Journal 2013; 34(2):187-9.

PMid: 23396467

5. Anık A, Çatlı G, Abacı A, Dizdarer C, Böber E. Vitamin D intoxication and multivitamin preparation. Journal of Clinical Research in Pediatric Endocrinology 2013; 5(2):136-9. http://dx.doi.org/10.4274/Jcrpe.896 PMid: 23748070 PMCid: PMC3701922

6. Lokadasan R, Prem S, Koshy SM, Jayasudha AV. Hypercalcaemia with disseminated osteolytic lesions: a rare 
presentation of childhood acute lymphoblastic leukaemia.

Ecancermedicalscience 2015; 9:542.

http://dx.doi.org/10.3332/ecancer.2015.54

2

PMid: 26082799 PMCid: PMC4462887

7. Barrueto F Jr, Wang-Flores HH, Howland MA, Hoffman RS, Nelson LS. Acute vitamin $\mathrm{D}$ intoxication in a child. Pediatrics. 2005; 116(3):e453-6.

http://dx.doi.org/10.1542/peds.2004-2580

PMid: 16140692

8. Barros ER, Saraiva GL, de Oliveira TP, Lazaretti-Castro M. Safety and efficacy of a 1-year treatment with zoledronic acid compared with pamidronate in children with osteogenesis imperfecta. Journal of Pediatric Endocrinology and Metabolism 2012; 25(5-6): 485-91.

http://dx.doi.org/10.1515/jpem-2012-0016

PMid: 22876543
9. Vuorimies I, Toiviainen-Salo S, Hero M, Mäkitie O: Zoledronic acid treatment in children with osteogenesis imperfecta; Hormone Research in Paediatrics 2011; 75(5):346-53.

http://dx.doi.org/10.1159/000323368

PMid: 21293106

10. F Del Porto, M Proietta, A Koverech, M Trappolini and G Aliberti: Hypercalcaemia in systemic lupus erythematosus. Lupus 2011; 20(7):758-62

http://dx.doi.org/10.1177/0961203310387 182

PMid: 21282297 